FEATURE

Keith Brook

Department for Business, Enterprise and Regulatory Reform

\title{
Performance and employment characteristics of the UK service industries, 1990-2008
}

S tatistics on the size of service sector industries and their international trade have been reviewed in a previous Economics and Labour Market Review (ELMR) paper (see Brook 2008). This included a discussion of developments in recent years to improve key outputs in response to a 1995 review of service sector statistics. While size and growth give some indications of the performance of the service sector, other measures such as profitability, prices, productivity and investment are also important. This paper describes these measures, together with some labour market characteristics.

Box 1 lists the relevant major outputs that the Office for National Statistics (ONS) produces and publishes. With the exception of the Annual Survey of Hours and Earnings (ASHE), none of the outputs include detailed quality measures, although some have limited quality measures or a quality report. Where possible, outputs are subdivided according to the Standard Industrial Classification (SIC) 2003, although due to quality limitations few publications give more detail than at section level. The service sector is defined by SIC sections G-Q.

The SIC classification has recently been the subject of an international and UK review. The revised classification is in the process of being implemented with a planned completion date of 2011 (see Box 3 in Brook 2008), and this will give some improvements to the scope and coverage of detailed service industries.

\section{Profitability}

In both the short or longer term, the survivability of an individual business and ultimately an industry depends to a large extent on its profitability. In recent years manufacturing industries in the developed world have seen increasing pressure on their profitability and, in some cases survivability, due to competition from countries where costs are lower. In many cases the response has been to outsource production activities abroad which, together with a significant reduction in transport and communication costs, have resulted in a change in the business model of many companies. Some service industries, such as the IT sector and call centre activities, are no longer immune from these changes and are also faced with the possibility of outsourcing and competition from abroad.

The profitability of UK private nonfinancial corporations has been published by ONS since the 1960s with quarterly data being available for companies in service industries from 1989. Figure 1 shows that, in terms of the percentage net rate of return, service industries have been consistently more profitable than manufacturing since 1989 and that the gap has widened since 1997. However, as might be expected, 2008 has shown a drop in profitability in the service industries as well as for manufacturing. No further industry breakdown is published within the service industries, and more detailed information is desirable, particularly as sectors perform 


\section{Box 1}

Summary of major sources and frequency of outputs measuring Service sector performance characteristics

Annual Survey of Hours and Earnings (ASHE) - annual: www.statistics.gov.uk/StatBase/Product.asp?vlnk=15050

Business Enterprise Research and Development, Business Monitor MA14 (BERD) - annual:

www.statistics.gov.uk/StatBase/Product.asp?vlnk=8206

Business Investment - quarterly

www.statistics.gov.uk/StatBase/Product.asp?vlnk=171\&Pos $=\&$ Col

Rank=1\&Rank=422

Consumer Price Indices (CPI) - monthly:

www.statistics.gov.uk/StatBase/Product.asp?vlnk=868

Foreign Direct Investment (FDI) - annual:

www.statistics.gov.uk/StatBase/Product.asp?vlnk=9614

Gross Domestic Expenditure on Research and Development

(GERD) - annual:

www.statistics. gov.uk/StatBase/Product. asp? $v$ lnk $=418 \&$ Pos $=1 \& C$

olRank=1\&Rank=256
Labour market statistics - monthly/quarterly:

www.statistics.gov.uk/StatBase/Product.asp?vlnk=1944

Producer Price indices, Business Monitor MM22 (PPI) - monthly: www.statistics.gov.uk/StatBase/Product.asp?vlnk=2208

Profitability of UK companies - quarterly:

www.statistics.gov.uk/StatBase/Product.asp?vInk=794

Productivity - quarterly:

www.statistics.gov.uk/StatBase/Product.asp?vlnk=7476

Services Producer Price Index, experimental (SPPI) - annual: www.statistics.gov.uk/StatBase/Product.asp?vlnk=7351\&Pos=3\& ColRank=2\&Rank=272

Survival rates of business enterprises - annual: www.statistics.gov.uk/StatBase/Product.asp?vlnk=15186

Vacancy survey of business enterprises - monthly: www. statistics. gov.uk/StatBase/Product.asp?vlnk=9390

\section{Figure 1}

\section{Net rate of return of UK companies by industry}

Per cent

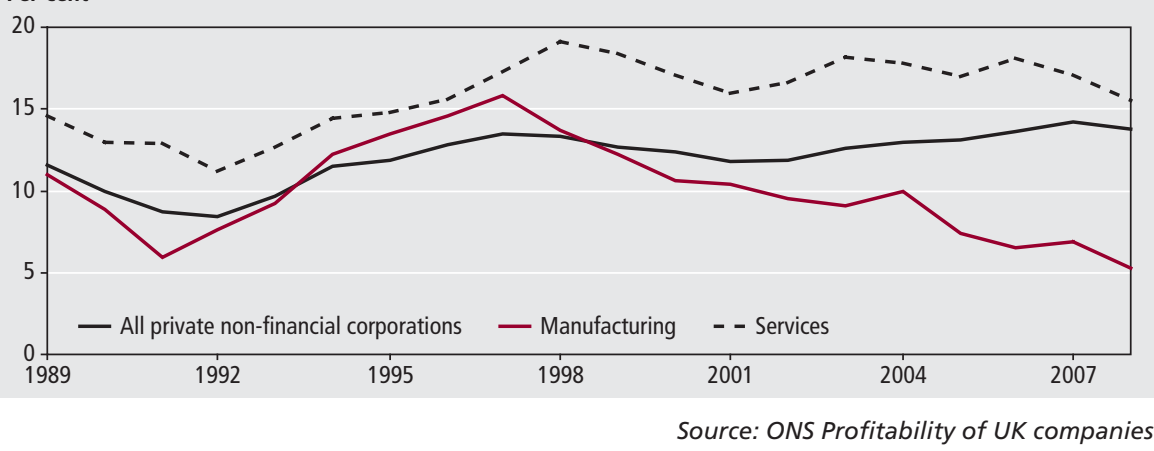

differently in the current economic downturn.

\section{Prices}

The profitability of companies is partly affected by prices. Service price indices and growths are published as a component of the Consumer Prices Index (CPI) and, for business services, in the Services Producer Prices Index (SPPI). Figure 2 shows the annual change in prices from 1989 for services and goods. The CPI is published monthly with services data being available from 1989, including a breakdown in terms of housing, travel and transportation, recreational and personal, communication and miscellaneous services.

Business output prices have been published on a monthly basis for manufactured goods since 1974 as part of the Producer Prices Index (PPI) and on a quarterly basis from 1996 for services (SPPI). The SPPI is currently an experimental series with coverage limited to key industries or products (see Table 5 in Brook 2008). Developments are ongoing to include other key industries in accordance with Eurostat requirements. When completed, this will provide coverage for about 60 per cent of corporate market services.

Figure 2 shows that between 1989 and 2007, price increases for services have generally been consistently higher than those for goods, with consumer goods showing price reductions for most years between 1990 and 2002. The purchase of consumer goods includes both those produced in the UK and also imports from abroad, and the reduction in prices for consumer goods is likely to have been mainly driven by cheaper imports. The drop in prices for consumer goods is consistent with the drop in profitability of manufacturing enterprises since 1997 (see Figure 1), suggesting that pricing pressures may have impacted on UK manufacturers' margins.

There was a large increase in the commodity price of oil, food and other energy items in the first half of 2008 which resulted in a significant increase in the price of manufactured goods for both producer and consumer prices. In 2008, services prices experienced little change with a relatively small increase. Driven by a fall in oil prices, manufacturers' input and output prices dropped in the second half of 2008, and it is expected that price changes might remain more muted in 2009.

\section{Productivity}

Sustained growth in productivity helps to maintain the profitability of businesses and indicate the well-being of an economy. International comparisons provide some insight into comparative advantage in relation to other countries. In 2006, the department of Trade and Industry (DTI), now part of the Department for Business, Enterprise and Regulatory Reform (BERR), published a report (see DTI 2006) which includes data for a range of productivity and competitiveness indicators. In many cases international comparisons with the USA, 


\section{Figure 2}

\section{Annual change in prices for UK goods and services}

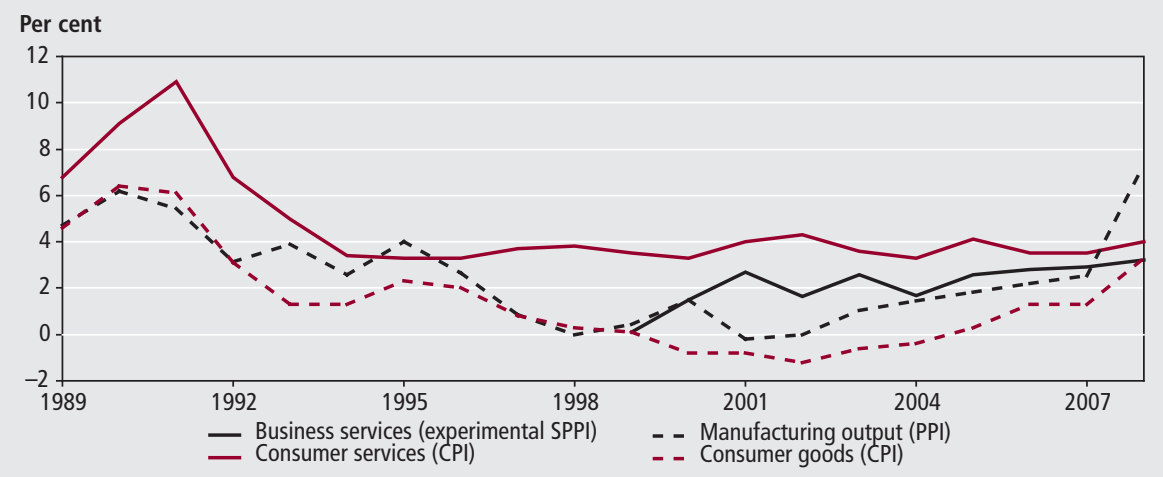

Source: ONS Consumer price indices, Producer prices and Services producer price index

France and Germany are given and the report covers a number of the performance measures discussed in this paper. BERR has recently published a further report examining the key issues and policies needed to raise UK productivity (BERR 2008a).

These reports do not include any sector breakdown by industry. In 2007 ONS published a productivity handbook giving a comprehensive overview of current practice and issues to be considered when measuring and developing UK productivity outputs. Chapter 8 of the handbook (see ONS 2007) includes a discussion of how service sector productivity can be measured. ONS publish annual and quarterly productivity indices for the whole economy (SIC sections A-Q), production (C-E), manufacturing (D) and its subsections, with some data being available from 1960.

For the service industries, quarterly indices are published in terms of output per job from 1978 for all services (G-Q), but indices are currently only published at section level for distribution, hotels and catering (G-H) from 1997. Output per hour data are also published from 1992. The service sector outputs have only recently been given National Statistics status and were published previously as experimental series. It is desirable that the productivity outputs are extended to all sections of the service sector, even if at first they only have experimental status.

Figure 3 shows the annual change in output per job for the available service outputs together with the whole economy and manufacturing. The annual change for services (G-Q) and the whole economy (A-Q) are in close agreement, which is to be expected since the economy is dominated by the service industries, which account for about 75 per cent of output and 80 per cent of jobs. Productivity growth for manufacturing (D) has generally been higher than for the whole economy and services. This is probably due to the movement of production jobs abroad or the outsourcing of service related activities. As expected, growth has dropped for all outputs over the last year as the economy has slowed in terms of output and employment.

As described in chapter 8 of the ONS

\section{Figure 3}

\section{Change in Output per job}

\section{Figure 4}

\section{Output per job in the services sector}

handbook (ONS 2007), productivity levels in terms of output per job can be estimated to give a more detailed industry breakdown using published Gross Value Added (GVA) and Workforce Jobs (WFJ) data. It is recognised that the productivity level of individual industries may not be directly comparable, particularly with the increasing polarisation of services into knowledgebased and labour intensive industries. However, comparisons of productivity levels can provide useful insights when taking into account the known structure of individual industries. Any estimation of growths from such data needs to be treated with caution and may need to be limited to longer term trends over 5 or 10 years, rather than annual changes.

Figure 4 shows the output per job of the service industries and for four section groupings, derived from published GVA and workforce jobs data. Finance, real estate, renting and other business activities (J-K) has the highest level of productivity while transport and communication (I) has seen the highest increase in productivity. It is expected that there will be large

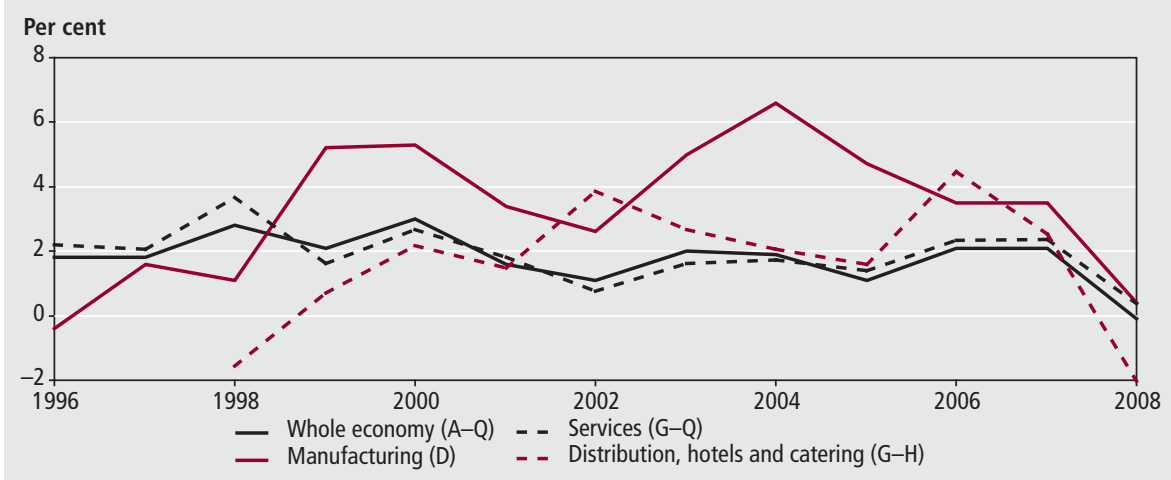

Source: Source ONS Productivity

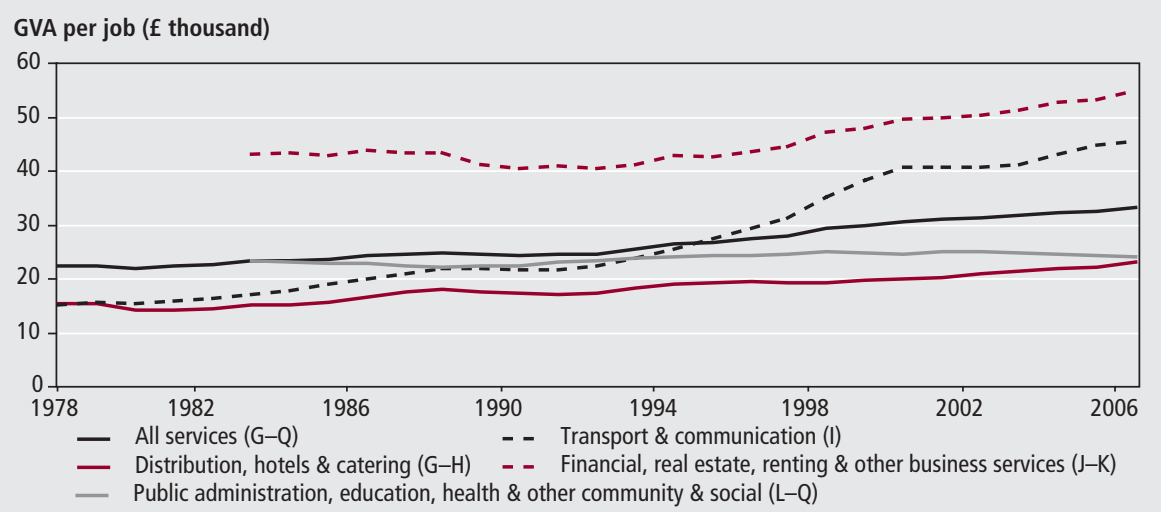

Source: ONS Quarterly National Accounts and Workforce Jobs 
differences in the productivity levels within these sections, for example within business services which include a wide range of industries with differences in labour intensity and skill levels. The estimation of productivity at a more detailed industry level will be discussed further in a future ELMR paper on financial and business services.

\section{Investment, R\&D and innovation}

The level of investment by a company can give some indication of its performance, although capital intensity differs according to industry. A detailed breakdown of UK investment in the service industries, in terms of Gross Capital Formation (GCF), is published annually in the UK National Accounts Blue Book, with consistent data being available from 1997. GCF is defined as acquisitions less disposals of fixed assets, improvements in land, valuables and change in inventories. GCF is limited to domestic investment in the UK and does not include investments abroad. The latter is defined as Foreign Direct Investment (FDI), which is described in the next section. FDI is different to GCF, both in terms of its definition and financial uses within the business.

Table 1 shows that in 2006, the level of GCF in all service industries was nearly five times that of the production industries, being $£ 126$ bn and $£ 26$ bn respectively. In the ONS source, a substantial proportion of the total GCF has not been allocated to an industry. This was 32 per cent in $2006, £ 75 \mathrm{bn}$ out of a UK total of $£ 233 \mathrm{bn}$.

The unallocated GCF includes investment in dwellings, transfer costs of land and existing buildings, and valuables. Hence it is not entirely appropriate to express GCF as a proportion of GVA within individual industries since the two measures are not consistent due to the unallocated GCF.

Within services, the highest investment in 2006 was in Financial and business services (J-K) with $£ 31$ bn, only slightly higher than Distribution, hotels and catering (G-H) and Transport and communication (I) with $£ 26$ bn and $£ 25$ bn respectively. The GCF in these three industries was in closer agreement in 1997, varying between $£ 17$ bn and $£ 19$ bn and it is possible that these levels may reduce in the current economic downturn.

The level of spending on Research and Development (R\&D) also provides some indication of industry performance and data is available for the UK from 1985.
Total UK spend on R\&D is dominated by private business enterprises, with additional spending coming from higher education, government, research councils and private non-profit organisations, as shown in

Figure 5. In 2007 R\&D expenditure by business enterprises was $£ 16.1$ billion, accounting for over 60 per cent of all spending which was $£ 25.5$ billion. This represents 1.8 per cent of UK Gross

Table 1

\section{Gross Capital Formation in the services industries}

\begin{tabular}{|c|c|c|c|c|c|}
\hline & & & & & billion \\
\hline Industry & SIC & 1997 & 2000 & 2003 & 2006 \\
\hline All industries & $A-Q$ & 142.9 & 172.4 & 190.6 & 232.5 \\
\hline Production & $C-E$ & 31.7 & 30.0 & 23.6 & 26.4 \\
\hline All services & $\mathrm{G}-\mathrm{Q}$ & 76.0 & 102.4 & 108.9 & 125.6 \\
\hline Distribution, hotels \& catering & $\mathrm{G}-\mathrm{H}$ & 18.3 & 20.4 & 19.4 & 26.4 \\
\hline Transport, storage \& communication & I & 17.3 & 26.6 & 23.6 & 24.9 \\
\hline Finance $\&$ business services & $J-K$ & 19.4 & 31.8 & 34.2 & 30.7 \\
\hline Public administration \& defence & $\mathrm{L}$ & 7.0 & 6.1 & 11.1 & 12.0 \\
\hline Education, health \& social work & $\mathrm{M}-\mathrm{N}$ & 5.6 & 6.9 & 9.4 & 13.3 \\
\hline Other social \& personal services & $0-Q$ & 8.5 & 10.7 & 11.0 & 18.2 \\
\hline Not allocated to industries ${ }^{1}$ & & 29.9 & 36.6 & 51.0 & 75.2 \\
\hline
\end{tabular}

Note:

Source: ONS Blue Book

1 Includes investment in dwellings, transfer costs of land and existing buildings, and valuables.

Figure 5

Gross domestic expenditure on R\&D in the UK, 2007

f billion

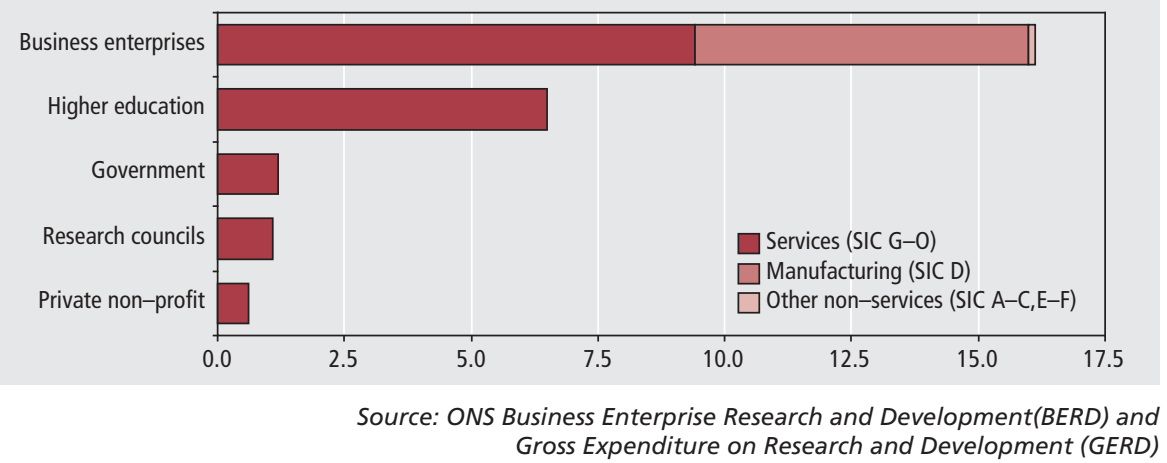

Table 2

\section{Expenditure on R\&D performed in UK businesses, $2007^{1}$}

\begin{tabular}{|c|c|c|c|c|c|c|}
\hline \multirow{2}{*}{ Industry } & \multirow[b]{2}{*}{$R \& D$ product } & \multirow[b]{2}{*}{1995} & & & \multicolumn{2}{|c|}{$£$ million } \\
\hline & & & 2000 & 2005 & 2006 & 2007 \\
\hline \multirow[t]{4}{*}{ All } & Total & 9,120 & 11,510 & 13,730 & 14,560 & 16,110 \\
\hline & Services & 1,670 & 1,900 & 2,950 & 3,430 & 3,780 \\
\hline & Manufacturing & 7,130 & 9,230 & 10,560 & 10,930 & 12,110 \\
\hline & Other non-services & 320 & 370 & 230 & 210 & 230 \\
\hline \multirow[t]{4}{*}{ Services } & Total & 3,190 & 5,360 & 7,130 & 8,140 & 9,420 \\
\hline & Services & 1,290 & 1,650 & 2,860 & 3,320 & 3,630 \\
\hline & Manufacturing & 1,860 & 3,570 & 4,130 & 4,700 & 5,680 \\
\hline & Other non-services & 40 & 140 & 150 & 120 & 110 \\
\hline \multirow[t]{4}{*}{ Manufacturing } & Total & 5,720 & 5,990 & 6,520 & 6,340 & 6,580 \\
\hline & Services & 380 & 250 & 90 & 100 & 150 \\
\hline & Manufacturing & 5,270 & 5,660 & 6,430 & 6,230 & 6,430 \\
\hline & Other non-services & 70 & 80 & - & 10 & 10 \\
\hline \multirow[t]{4}{*}{ Other non-service } & Total & 210 & 160 & 80 & 90 & 120 \\
\hline & Services & - & - & 10 & 10 & - \\
\hline & Manufacturing & - & - & - & - & 10 \\
\hline & Other non-services & 210 & 160 & 70 & 80 & 110 \\
\hline
\end{tabular}

Notes:

Source: ONS BERD

1 Data are rounded to the nearest $f 10$ million.

'-' denotes a value of less than $f 10$ million. 
Table 3

\section{Patterns in innovation in services}

\begin{tabular}{|c|c|c|c|c|c|}
\hline & $\begin{array}{l}\text { Supplier } \\
\text { dominated }\end{array}$ & $\begin{array}{l}\text { Innovation in } \\
\text { services }\end{array}$ & $\begin{array}{l}\text { Client-led } \\
\text { innovation }\end{array}$ & $\begin{array}{l}\text { Innovation } \\
\text { through services }\end{array}$ & $\begin{array}{l}\text { Paradigmatic } \\
\text { innovation }\end{array}$ \\
\hline Retailing & $\begin{array}{l}\text { Scanning } \\
\text { registers/stock } \\
\text { replenishment } \\
\text { systems }\end{array}$ & $\begin{array}{l}\text { New shop } \\
\text { formulae/new } \\
\text { franchise schemes }\end{array}$ & $\begin{array}{l}\text { Green or } \\
\text { "organic" product/ } \\
\text { home delivery }\end{array}$ & $\begin{array}{l}\text { Retail consultants } \\
\text { introducing } \\
\text { new formulae } \\
\text { or marketing } \\
\text { strategies }\end{array}$ & E-commerce \\
\hline $\begin{array}{l}\text { Transport and } \\
\text { logistic services }\end{array}$ & $\begin{array}{l}\text { On board } \\
\text { computers }\end{array}$ & $\begin{array}{l}\text { New logistic } \\
\text { concepts mostly } \\
\text { streamlining value } \\
\text { chains and adding } \\
\text { information to it }\end{array}$ & $\begin{array}{l}\text { Outsourcing of } \\
\text { transport and } \\
\text { "light" production/ } \\
\text { assembly }\end{array}$ & $\begin{array}{l}\text { Shippers offering } \\
\text { clients tracking } \\
\text { and tracing } \\
\text { facilities and so } \\
\text { contribute to } \\
\text { reductions in } \\
\text { stocks }\end{array}$ & $\begin{array}{l}\text { Containerisation, } \\
\text { e-commerce }\end{array}$ \\
\hline $\begin{array}{l}\text { Financial } \\
\text { services }\end{array}$ & $\begin{array}{l}\text { New distribution } \\
\text { channels based on } \\
\text { technical platforms } \\
\text { (SMS alerts, new } \\
\text { mobile devices), } \\
\text { back office } \\
\text { automation }\end{array}$ & $\begin{array}{l}\text { New (customised) } \\
\text { financial services } \\
\text { concepts, } \\
\text { multi channel } \\
\text { management }\end{array}$ & $\begin{array}{l}\text { Green banking, } \\
\text { products covering } \\
\text { various stages in } \\
\text { life e.g. starter } \\
\text { mortgage or estate } \\
\text { planning }\end{array}$ & $\begin{array}{l}\text { Financial } \\
\text { constructions e.g } \\
\text { sale and lease } \\
\text { back }\end{array}$ & $\begin{array}{l}\text { Multi-functional } \\
\text { smart cards } \\
\text { (including non- } \\
\text { financial functions) }\end{array}$ \\
\hline
\end{tabular}

Source: See Table 1.1 in DTI(2007)

Domestic Product (GDP), which is slightly below a government target of 2 per cent.

Figure 5 shows that in 2007, over half of the source of business spending was from service industries, with the majority of the remainder being from manufacturing industries. However, as shown in Table 2 a significant proportion of the business $R \& D$ expenditure by service industries, which includes the R\&D industry as part of business services (SIC 73), was on R\&D for manufacturing products.

Scientific $R \& D$ is one of a number of different kinds of intangible investments. Some investments such as computer software, databases, mineral exploration and copyright and license costs are already treated as intangible investments in the UK National Accounts. Other potential intangibles, not currently included, are the development of new architectural and engineering designs, branding and organisational structures. However, there is currently no international consensus on how to measure such intangibles. In 2007, the UK Treasury published a report of an investigation into such measures and their potential impact on UK productivity (see HMT 2007).

The former DTI also investigated wider measures of innovation within the service industries (see DTI 2007). Five main types of innovation were identified:

- reliance on external innovation 'supplier dominated'

- intensity of in-house innovation 'innovation in services'

\section{Foreign Direct Investment}

FDI gives a measure of flows of investment into the UK by international firms (inward FDI) and out of the UK by UK-owned businesses making acquisitions abroad (outward FDI). Only investments that produce a lasting interest in an enterprise are included where the investor's purpose is to have an effective voice in the management of the enterprise. By international agreement this is taken as equivalent to holding 10 per cent or more of the share capital in the direct investment enterprise.

Investment figures are published on a net basis, that is, they consist of investments less dis-investments by a company. Acquisitions or disposals in a given year or sector can be volatile and a single large merger in one year can give the impression that there has been a substantial decline in subsequent years. The net cumulative stock provides a more stable picture. The industry classification is defined by the activity of the firm that is being invested in, so inward FDI is classified by the UK industry, and outward FDI by the industry of the foreign affiliate. However, a recent analysis by ONS on behalf of BERR indicated that the majority of acquisitions occur within the same industry sector in both countries.

Figure 6 shows that UK FDI increased steadily between 1997 and 2000 for outward FDI, and in Figure 7 since 2001 for inward FDI. Activity then dropped off following the burst of the dot-com bubble in late 1999 / early 2000. Following little growth in stock until 2004, both outward and inward FDI have grown in the three years to 2007 .

Both service and non-service industries have seen growth in FDI over the last ten years. Outward FDI in the service

\section{Figure 6}

\section{Outward FDI by industry}

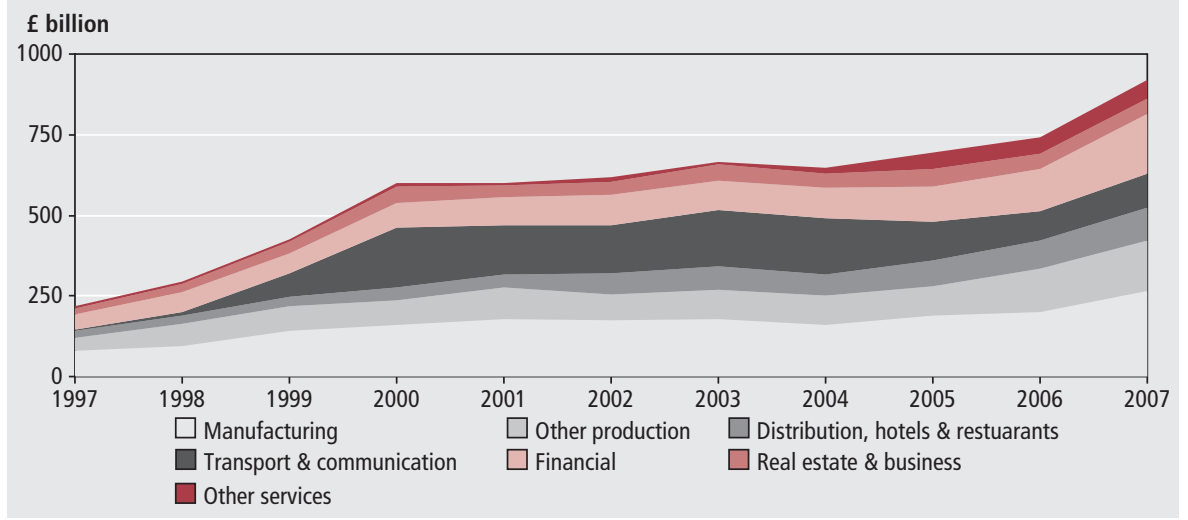




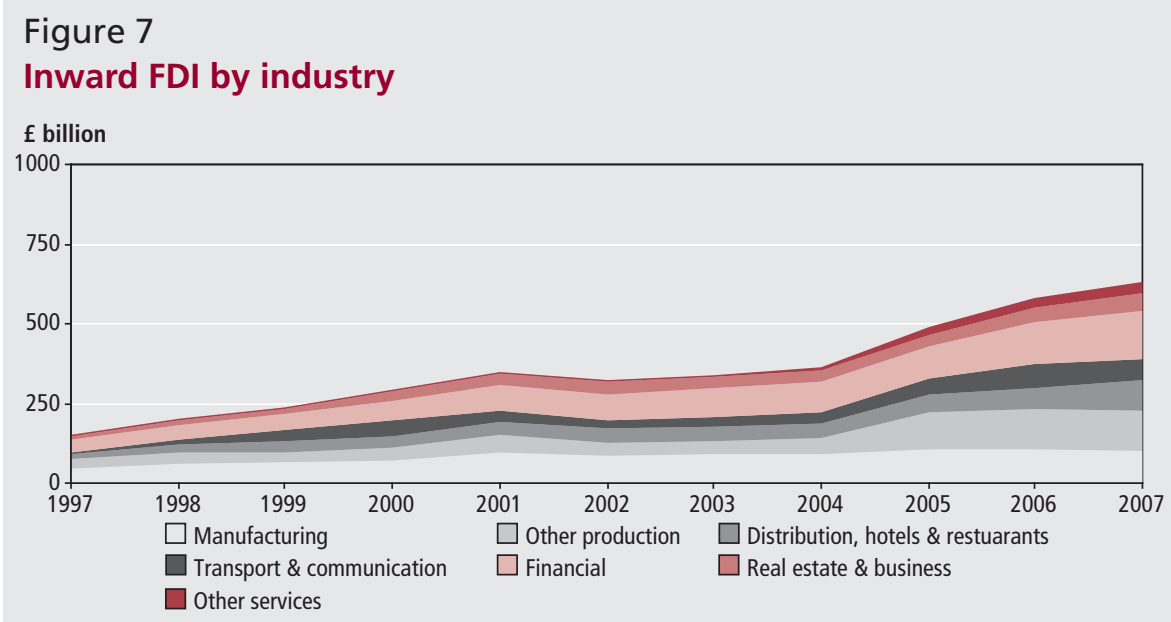

Source: ONS Foreign Direct Investment

industries totaled nearly $£ 100$ billion in 1997, 45 per cent of all outward FDI, and this has increased to nearly $£ 500$ billion in 2007, now 54 per cent of the UK total. Within services the highest acquisitions were in the transport and communications sector between 1997 and 2004, but this has decreased in recent years. Since 2004 the highest acquisitions have been in financial services with other services also showing some growth.

Inward FDI in the service industries was nearly $£ 80$ billion in 1997,51 per cent of all inward FDI, and this has increased to over $£ 400$ billion in 2007,64 per cent of the UK total for all industries. Within services, the largest share has been in the financial services sector until 2005 but has been in transport and communication in 2006 and 2007.

Preliminary estimates for 2008, which do not include a sectoral breakdown, indicate that these investment levels have been maintained with outward and inward FDI increasing to $£ 1,036$ bn and $£ 674$ bn respectively at the end of 2008, compared with $£ 919$ bn and $£ 630$ bn at the end of 2007 .

\section{Foreign Affiliates Statistics}

Published FDI data includes a measure of annual remittances derived from the net stocks but this is not a comprehensive measure of activity. Wider measures of activity such as turnover, employment and external trade are not available for FDI activity. However, Foreign Affiliates Trade statistics (FATS) are being developed by the UK in accordance with a Eurostat regulation (see Eurostat 2007) which requires member states to report inward and outward FATS data, starting from a reference year of 2007.

A foreign affiliate is defined as a business
Business Inquiry (ABI). The ABI is sampled from the Inter-Departmental Business Register (IDBR), which includes the foreign ownership attribute of each business. Work is in hand to improve the quality and reliability of this key attribute and it is planned that inward FATS data will be produced for the UK towards the end of 2009 , with data being available from the 2007 reporting year. This will include a number of attributes such as turnover and employment, including a split by industry.

These same attributes also need to be derived for outward FATS but measurement is more difficult since data needs to be collected for activity outside of the UK. A new survey is being developed by ONS and work is currently in hand to develop a questionnaire and address population and sampling issues. Pilot surveys are planned for 2009 and 2010 with the first full survey being planned for 2011 for reporting year 2010.

\section{Employment characteristics}

Variations in employment characteristics can arise within different industries for a number of reasons. On the supply side, the UK labour market has evolved and become more flexible in recent decades. On the demand side, different industries have increasingly specialised requirements from
For the UK, inward FATS are being derived from data collected in the Annual

Table 4

\section{Composition of service sector employment, 2008 Q2}

\begin{tabular}{lrrrrr}
\hline & & & & Percentages \\
\hline & Female & Part-time & Temporary & $\begin{array}{r}\text { Self- } \\
\text { employed }\end{array}$ & $\begin{array}{r}\text { Professional } \\
\text { occupation }\end{array}$ \\
\hline Distribution, hotels \& restaurants (G-H) & 50 & 40 & 4 & 10 & 34 \\
Transport \& communication (I) & 24 & 13 & 3 & 13 & 36 \\
Financial \& other business activities (J-K) & 43 & 19 & 4 & 16 & 81 \\
Public admin, education \& health (L-N) & 69 & 33 & 8 & 5 & 68 \\
Other services (O-Q) & 53 & 35 & 10 & 26 & 54 \\
Total Services (G-Q) & 54 & 30 & 6 & 11 & 59 \\
All industries (A-Q) & 46 & 25 & 5 & 13 & 54 \\
\hline
\end{tabular}

Source: ONS Labour Force Survey

\section{Figure 8}

\section{Age distribution of service sector employment, 2008 Q2}

Per cent

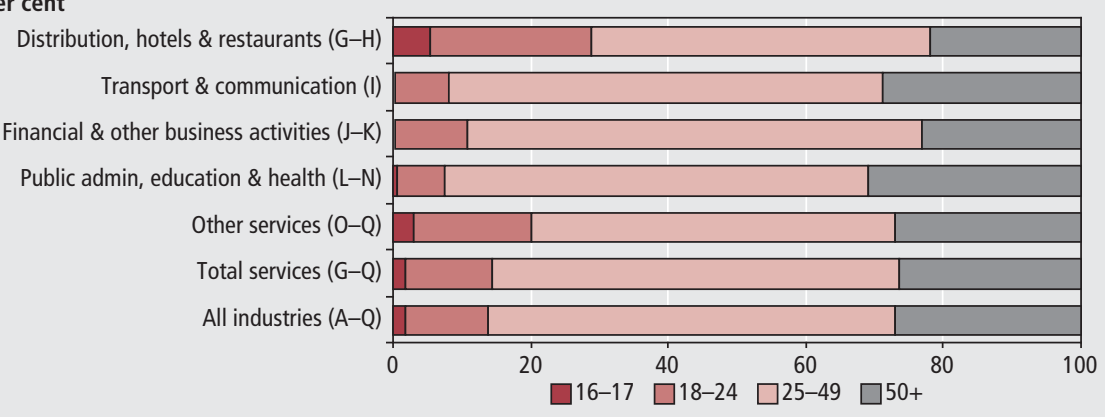

Source: ONS Labour Force Survey 


\section{Figure 9}

\section{Highest qualification distribution of service sector employment, 2008 Q2}

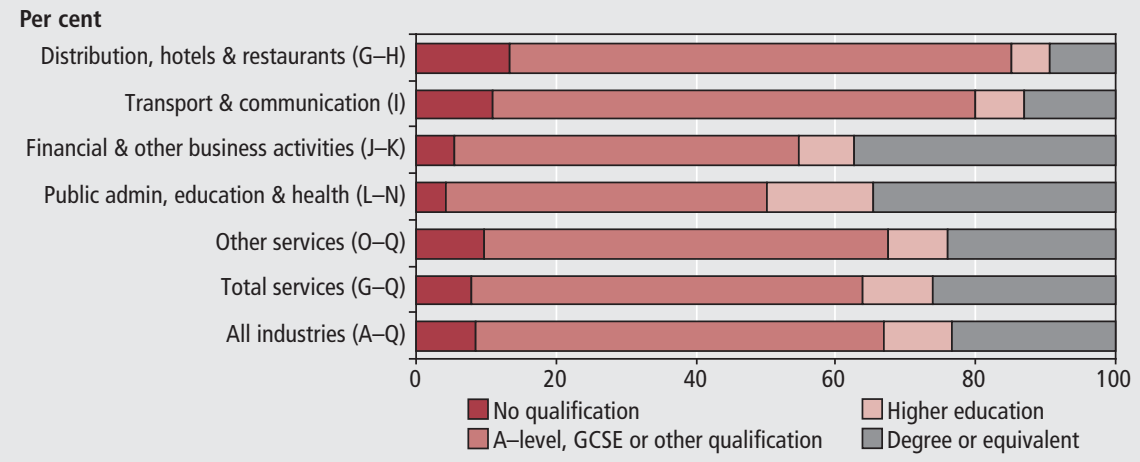

Source: ONS Labour Force Survey

Figure 10

\section{Service sector employment of non-white ethnicities}

Per cent

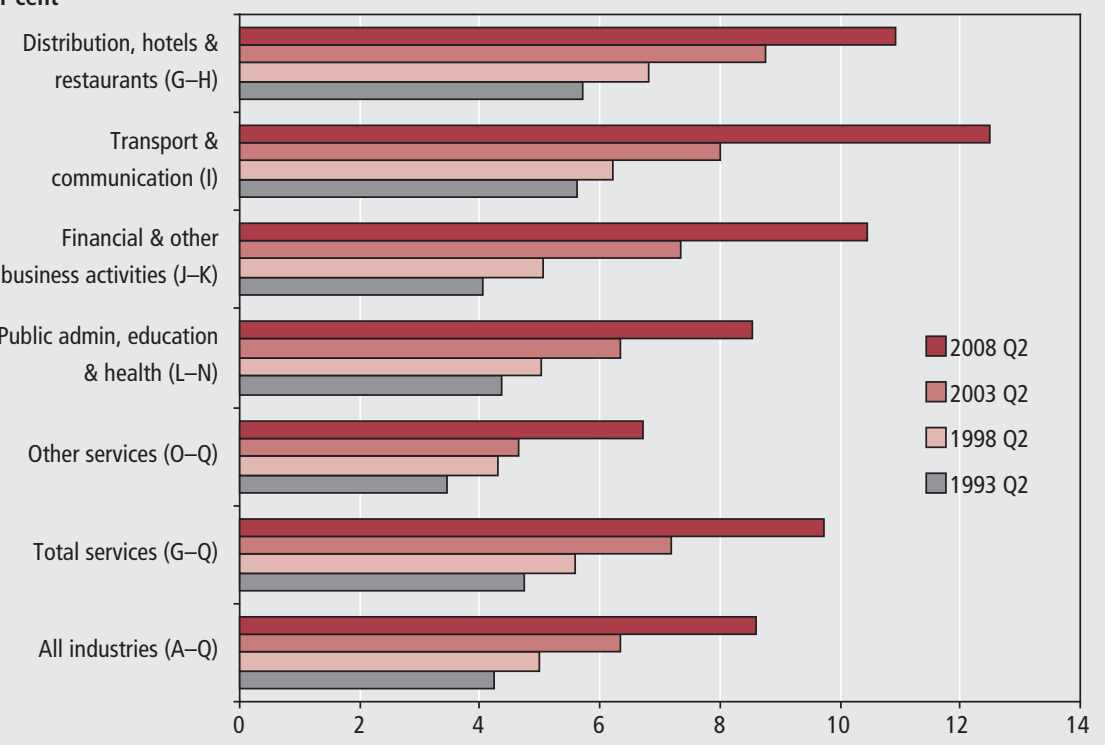

Source: ONS Labour Force Survey

\section{Figure 11}

\section{Service sector employment of non-UK nationals}

Per cent

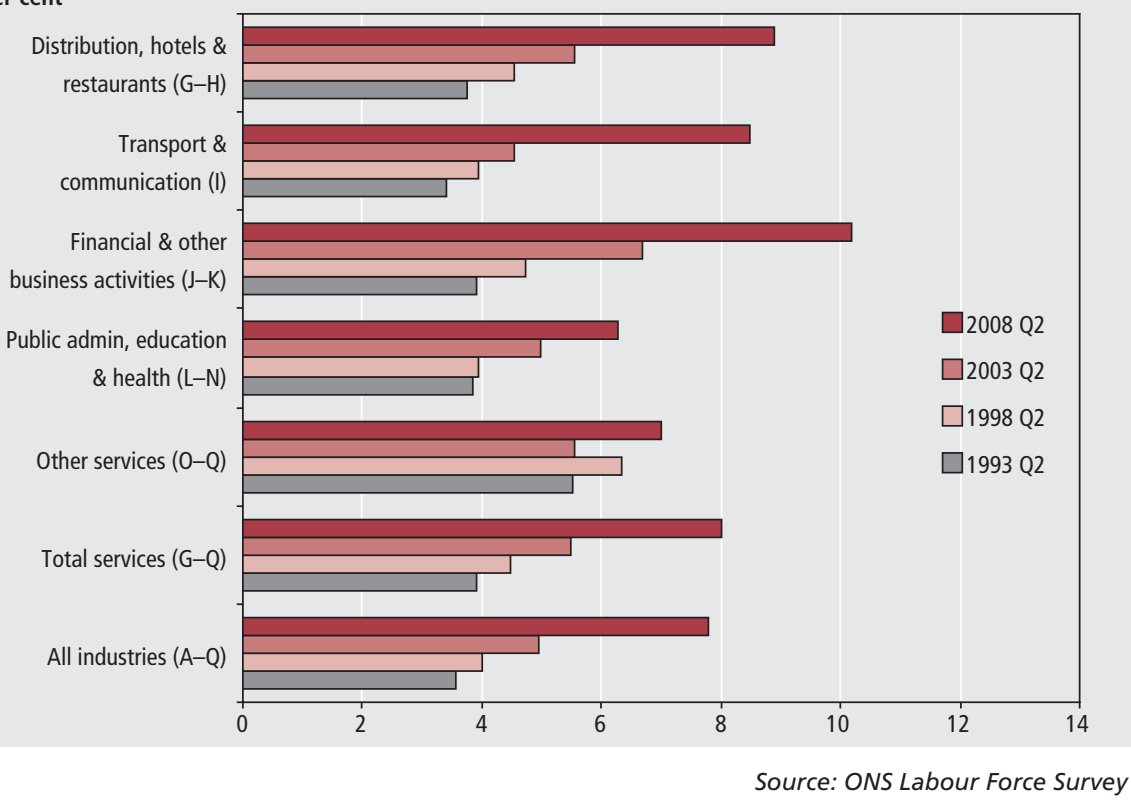

the labour force, for example in terms of skills.

It is possible to determine employment characteristics on an industry basis using data from the quarterly Labour Force Survey (LFS), which is a household rather than a business survey. Although the survey questionnaire has changed and evolved over time, there is reasonable continuity from 1992 for many of the key variables.

Table 4 shows the percentage employed in the service industries in 2008 quarter 2 for five key characteristics. Total services has a higher proportion of female, part-time, temporary and professional occupation workers than the all industries category. However, self-employment is slightly below the rate for all industries. Within the service industries, these characteristics vary considerably. The transport and communication industry has the lowest rates for female and parttime working. Public administration has the highest female rate, and distribution, hotels and restaurants the highest parttime rate. Temporary working and selfemployment are highest in other services; and professional occupations are highest in financial and other business activities.

Figure 8 shows the age and Figure 9 the highest qualification distributions of employment within the service industries. There is little difference between the age distribution for all industries and total services, but differences exist within services, notably the 16-17 age group is primarily limited to distribution, hotels and restaurants which includes fast-food outlets, and other services which includes leisure activities. Public administration has the highest proportion employed aged 50 or over. This industry, together with transport and communication also has the lowest proportion employed aged 18-24, possibly due to a greater degree of job security and higher retention rates. In terms of highest qualification, Financial and other business activities and public administration have the highest proportion employed with a degree or equivalent, while distribution, hotels and restaurants and transport and communication have the lowest.

Figure $\mathbf{1 0}$ shows that there has been a relatively large increase in the percentage employed who are from non-white ethnic groups over the 15 year period between 1993 and 2008. These increases are consistent throughout all of the service 


\section{Figure 12 \\ Proportion of service sector workers with usual hours over $\mathbf{4 8}$ hours per week}

Per cent

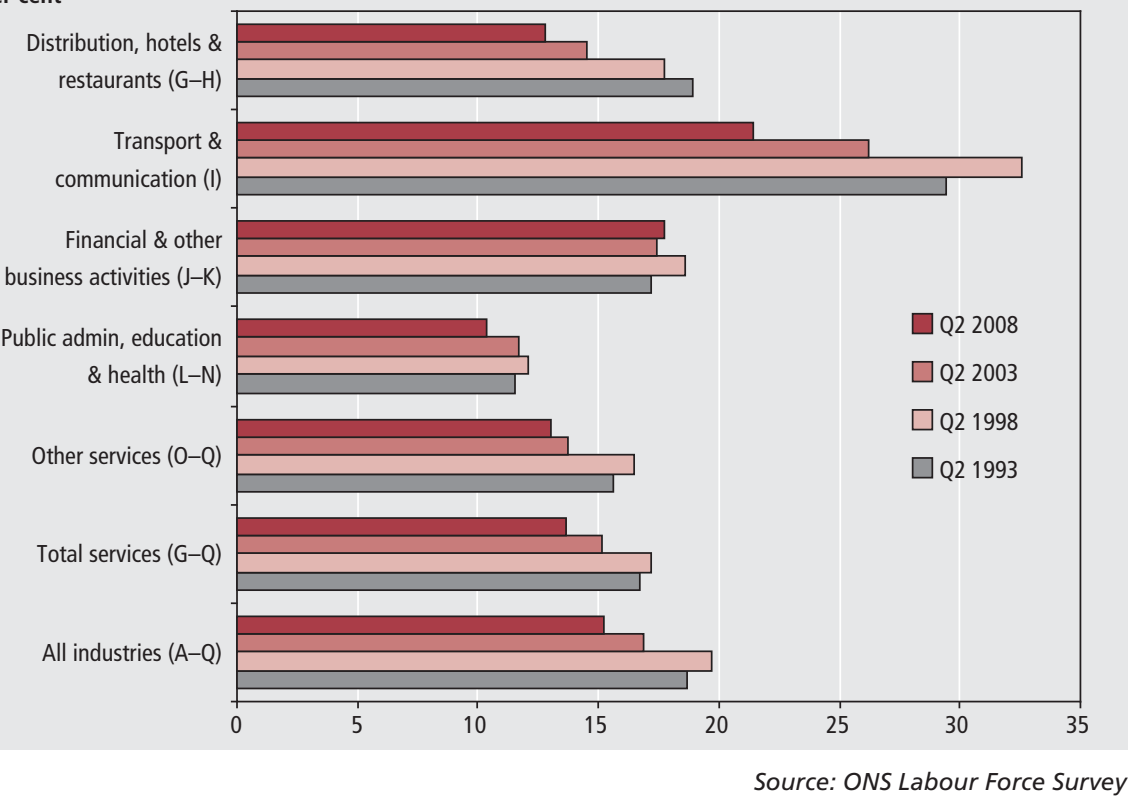

Figure 13

\section{Proportion of service sector workers with a second job}

Per cent

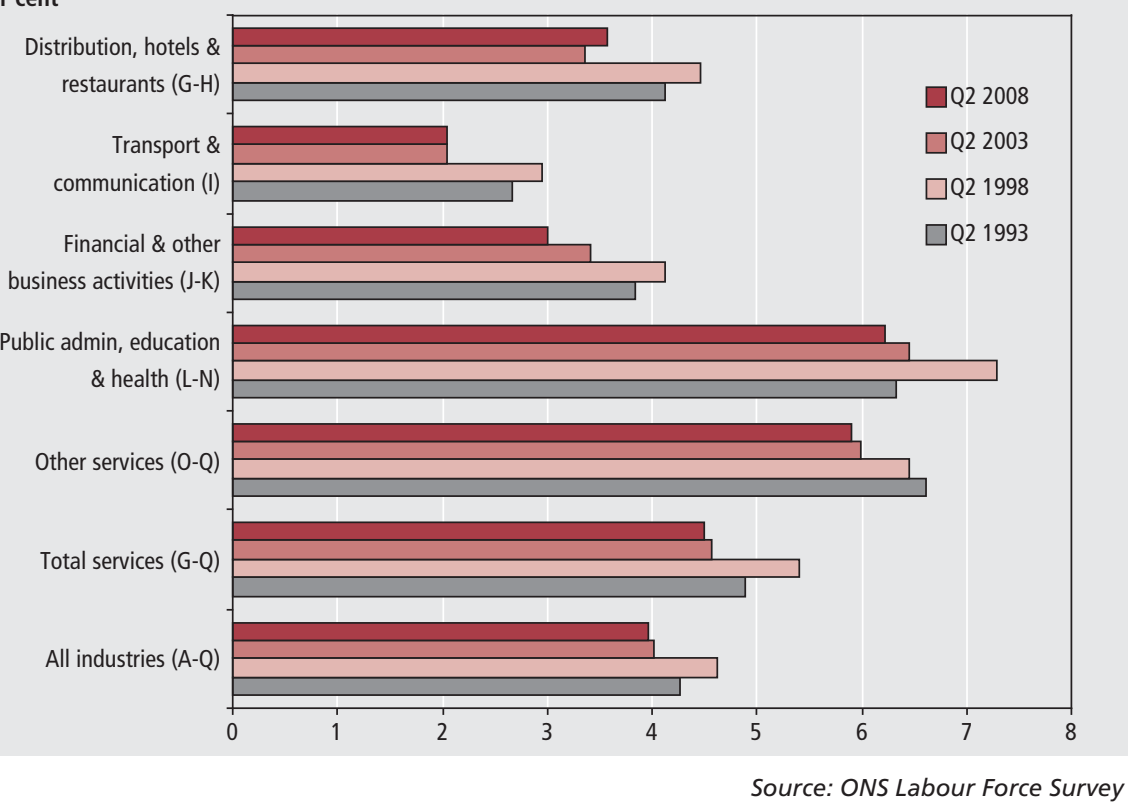

industries with the highest rates, in excess of 10 per cent in 2008, occurring in three industry groups - distribution, transport and communication and financial and other business activities. This growth is due to immigration and second generation children becoming working age. The increases observed in the financial and other business activities and in public administration may indicate that skill levels are increasing among the non-white ethnic groups.

Figure 11 also shows the increase in non-UK nationals employed in the service limit the number of hours an individual can work to an average of 48 hours per week (see www.berr.gov.uk/whatwedo/ employment/employment-legislation/ working-time-regs/index.html). In the $\mathrm{UK}$ an individual can opt-out through a voluntary agreement. Figure 12 shows that between 1993 and 1998, there was an increase in the percentage of employees who worked more than 48 hours per week in their main and any second job, being just over 17 per cent in total services in 1998. Hours worked include any regular paid and unpaid overtime. Between 1998 and 2008, the rate dropped to 14 per cent. These rates are slightly below those for all industries which exhibits a similar trend. Within the service industries, transport and communication had the highest rate in 2008 at 21 per cent, down from a peak of 33 per cent in 1998. Public administration had the lowest rate in 2008 at 10 per cent.

Working long hours may be partly due to an individual holding two or more jobs. Figure 13 shows that the percentage of employees who hold a second job has followed a similar pattern to that of working long hours, with increases between 1993 and 1998 and reductions between 1998 and 2008. The industry is defined in terms of the employee's first job and the industry of the second job is not shown, although this is recorded in the LFS. The service industries with the highest and lowest rates are almost opposite to that for working long hours, with public administration and other services both recording the highest rate at about 6 per cent in 2008 and transport and communication having the lowest rate at 2 per cent.

\section{Earnings and hours worked}

Earnings and hours worked data are measured by the Annual survey of Hours and Earnings (ASHE). ASHE is a business survey which uses a 1 per cent random sample of all employees registered for pay as you earn (PAYE) with Her Majesty's Revenue and Customs (HMRC). ASHE replaced the New Earnings Survey (NES) in 2004 and introduced a number of major improvements including imputation for non-response and weighting to UK totals based on the LFS. Supplementary sources were also introduced to improve the estimates for those on low incomes, who are under-represented in ASHE since they may not be registered for PAYE.

Median has replaced average earnings 
Table 5

Gross hourly pay for all employee jobs, $2008^{1}$

\begin{tabular}{|c|c|c|c|c|c|c|c|}
\hline \multirow[b]{4}{*}{ Section } & \multirow[b]{4}{*}{ Industry } & & & & & \multicolumn{2}{|c|}{$f$ and percentages } \\
\hline & & \multicolumn{4}{|c|}{ Full-time } & Part- & \\
\hline & & & $\begin{array}{l}\text { Per cent } \\
\text { change }\end{array}$ & & & & \\
\hline & & All employees & $2007 / 08$ & Male & Female & Male & Female \\
\hline $\mathrm{G}-\mathrm{Q}$ & Services & 12.0 & 4.0 & 12.9 & 11.1 & 7.1 & 7.5 \\
\hline G & Wholesale \& retail trade & 9.2 & 3.3 & 10.0 & 8.1 & 6.1 & 6.1 \\
\hline $\mathrm{H}$ & Hotels \& restaurants & 7.0 & 2.2 & 7.3 & 6.7 & 5.6 & 5.6 \\
\hline I & Transport \& communication & 11.2 & 3.7 & 11.3 & 11.1 & 8.9 & 9.0 \\
\hline J & Financial intermediation & 16.5 & 6.6 & 21.3 & 12.5 & 10.9 & 10.0 \\
\hline $\mathrm{K}$ & Real estate, renting \& business activities & 13.1 & 3.6 & 14.4 & 11.5 & 7.3 & 7.8 \\
\hline L & Public administration \& defence & 13.5 & 5.5 & 14.9 & 11.6 & 13.0 & 9.7 \\
\hline M & Education & 14.6 & 3.2 & 15.7 & 13.8 & 11.7 & 8.2 \\
\hline $\mathrm{N}$ & Health \& social work & 12.0 & 3.7 & 14.0 & 11.3 & 10.0 & 8.8 \\
\hline 0 & Other social \& personal & 10.6 & 3.5 & 11.1 & 9.7 & 7.2 & 7.0 \\
\hline$P$ & Private households & 9.1 & 15.3 & 10.9 & 9.0 & 9.2 & 7.7 \\
\hline Q & Extra-territorial & 17.0 & * & 16.9 & * & * & 6.7 \\
\hline$A-Q$ & All industries & 12.0 & 4.3 & 12.6 & 10.9 & 7.3 & 7.5 \\
\hline
\end{tabular}

Notes:

Source: ONS Annual Survey of Hours and Earnings

1 * sample size too small to provide estimates

Key CV $<=5 \%$

$\mathrm{CV}>5 \%$ and $<=10 \%$

$\mathrm{CV}>10 \%$

Table 6

Median total hours of weekly paid work for all employee jobs, 2008

\begin{tabular}{|c|c|c|c|c|c|c|c|}
\hline & & & & & & Hours & centages \\
\hline & & & Full-t & & & Part- & \\
\hline & & & $\begin{array}{l}\text { Per cent } \\
\text { change }\end{array}$ & & & & \\
\hline Section & Industry & All employees & $2007 / 08$ & Male & Female & Male & Female \\
\hline G-Q & Services & 37.5 & 0.0 & 38.2 & 37.0 & 17.2 & 19.1 \\
\hline G & Wholesale \& retail trade & 39.2 & -0.4 & 40.0 & 37.6 & 17.3 & 19.0 \\
\hline $\mathrm{H}$ & Hotels \& restaurants & 40.0 & 0.0 & 40.0 & 39.8 & 16.6 & 16.1 \\
\hline I & Transport \& communication & 40.0 & 0.0 & 40.0 & 37.7 & 21.5 & 21.3 \\
\hline J & Financial intermediation & 35.0 & 0.0 & 35.0 & 35.0 & 20.1 & 21.0 \\
\hline K & Real estate, renting $\&$ business activities & 37.5 & 0.0 & 37.5 & 37.5 & 17.5 & 18.2 \\
\hline L & Public administration \& defence & 37.5 & 1.0 & 39.9 & 37.0 & 18.5 & 21.0 \\
\hline M & Education & 36.1 & 0.0 & 37.0 & 35.0 & 15.2 & 18.5 \\
\hline $\mathrm{N}$ & Health \& social work & 37.5 & 0.0 & 37.5 & 37.5 & 18.0 & 20.6 \\
\hline 0 & Other social \& personal & 38.8 & 2.2 & 39.9 & 37.5 & 15.0 & 17.0 \\
\hline$P$ & Private households & 40.0 & -0.1 & 38.2 & 40.0 & * & 14.2 \\
\hline Q & Extra-territorial & 37.5 & -1.1 & 37.3 & * & * & * \\
\hline$A-Q$ & All industries & 37.5 & 0.0 & 39.0 & 37.1 & 17.5 & 19.3 \\
\hline
\end{tabular}

Notes:

Source: ONS Annual Survey of Hours and Earnings

1 * sample size too small to provide estimates

Key $\mathrm{CV}<=5 \%$

CV $>5 \%$ and $<=10 \%$

CV $>10 \%$

as the preferred measure for ASHE. The median is considered to be a better measure to reduce any distortion on average earnings arising from respondents with very high or low incomes, particularly where sample sizes are small for some detailed industries. Table 5 and Table 6 show the median gross hourly earnings and paid hours worked for employees in the service industries in 2007. This includes usual hours worked together with any paid overtime. Earnings and hours worked are shown separately for full-time and part-time employees with a male and female split. Unpaid overtime is not recorded in ASHE and data cannot be analysed for individual employees, hence the LFS is used to investigate working long hours (see Figure 12).

Table 5 shows that median hourly earnings for full-time employees in the service industries was $£ 12.00$ in 2008 , a growth of 4 per cent compared with 2007. The highest median earnings were in financial intermediation with $£ 16.50$, which also had the lowest median hours worked at 35 hours compared with 37.5 for all services. The lowest median earnings in the service industries was recorded for hotels and restaurants at $£ 7.00$, which together with transport and communication had the highest weekly hours worked at 40 hours.

Another major improvement introduced in ASHE is the publication of quality measures in terms of the coefficient of variation $(\mathrm{CV})$. These are given individually for all outputs in separate supplementary 


\section{Figure 14}

\section{Proportion of jobs paid below the National Minimum Wage}

Per cent

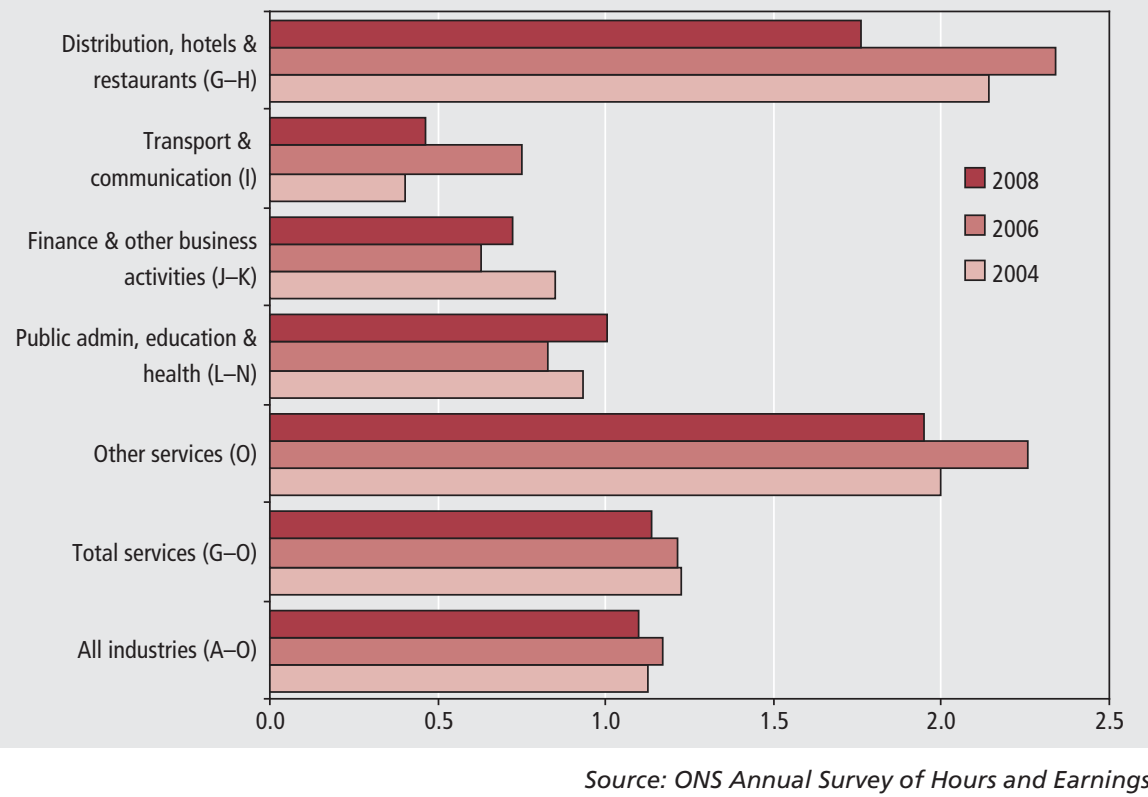

Figure 15

3 and 5 year survival rates of business enterprises registered in 2002

Per cent

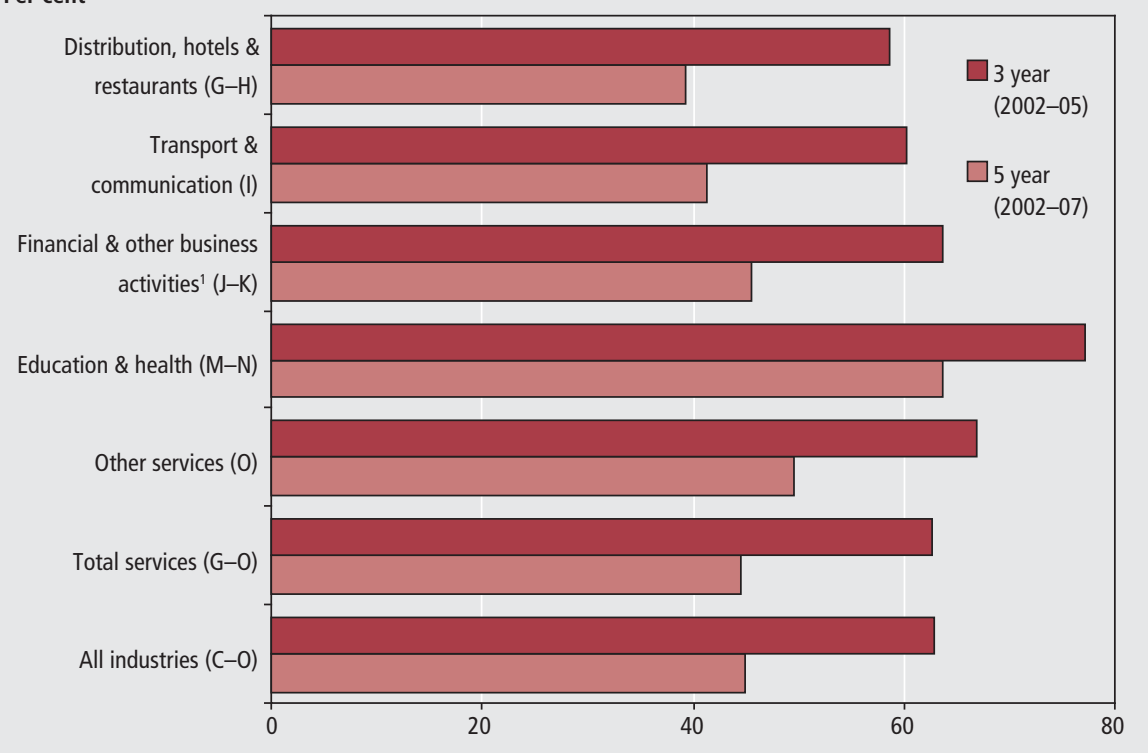

Note:

1 Excludes SIC 74.15 Managed service companies

tables and, in addition, outputs in the main tables are colour coded using a banded $\mathrm{CV}$ measure, as shown in Tables 5 and 6. This high standard for the provision and presentation of quality measures is a welcome improvement and where possible should be mirrored in some suitable format for all official statistics outputs.

The Low Pay Commission (LPC) makes extensive use of ASHE data and further analysis is undertaken on their behalf by the ONS. This supports an annual review of the level of the National Minimum wage (NMW), which was introduced in the UK
Source: ONS Survival rates of business enterprises

in 1999. Figure 14 shows the percentage of jobs paid below the NMW within the service industries in 2004, 2006 and 2008. Data is not available before 2004 on a consistent basis.

In 2008, 1.1 per cent of jobs in total services were reported to be paid below the National Minimum Wage (NMW), slightly higher than the rate for all industries. These rates have changed little over the four year period. Within the service industries, other services had the highest rate in 2008 at nearly 2 per cent down from 2.3 per cent in 2006. Distribution, hotels and restaurants recorded the second highest rate at 1.8 per cent in 2008, also down from 2.3 per cent in 2006. The remaining service industries reported rates below those for total services, with transport and communication having the lowest rate at nearly 0.5 per cent in 2008. It should be noted that the change in rates between years could be within the sampling variability of the estimates, and may not be significant.

\section{Business survival rates, redundancies and vacancies} ONS publish business demography characteristics and from 2008 this has been extended to include registrations (births), de-registrations (deaths) and survival rates of private enterprises. Data are given at national, regional and local authority level together with an industry breakdown. A similar analysis was previously published by the former DTI until 2005 reference year. Figure 15 shows the three and five year survival rates of business enterprises registered in 2002. For total services, the three year survival rate was 63 per cent, dropping to 44 per cent after five years in 2007. With the exception of education and health, the survival rates for the different services sectors are similar to the rates for total services. Although the survival rate may not appear high over a five year period, overall the stock in terms of the count of live business enterprises increases each year since the number of deaths is less than the number of births.

Redundancy and vacancy data are also available for the service industries, with levels and rates published quarterly. Seasonal variations are normally manifest in most industries for both series. Consistent redundancy data derived from the LFS is available from 1998 and rates for selected years since 1998, together with data for each quarter of 2008, are given in Table 7.

Redundancy rates within the different service industries are consistently lower for each year than for the Manufacturing and Construction industries. In 2008 quarter one, the total services rate was 3.7 redundancies per 1000 employees, compared with rates of 8.4 and 11.1 for manufacturing and construction. These rates have increased throughout the year to $7.3,18.3$ and 31.3 respectively in 2008 quarter four. Within the service industries in quarter 4 2008, Public administration, education and health had the lowest rate of 1.8 and Financial and other business activities had the highest rate of 12.8 , closely 
Table 7

\section{Redundancy rates in the services sector ${ }^{1}$}

Rate per 1,000 employees

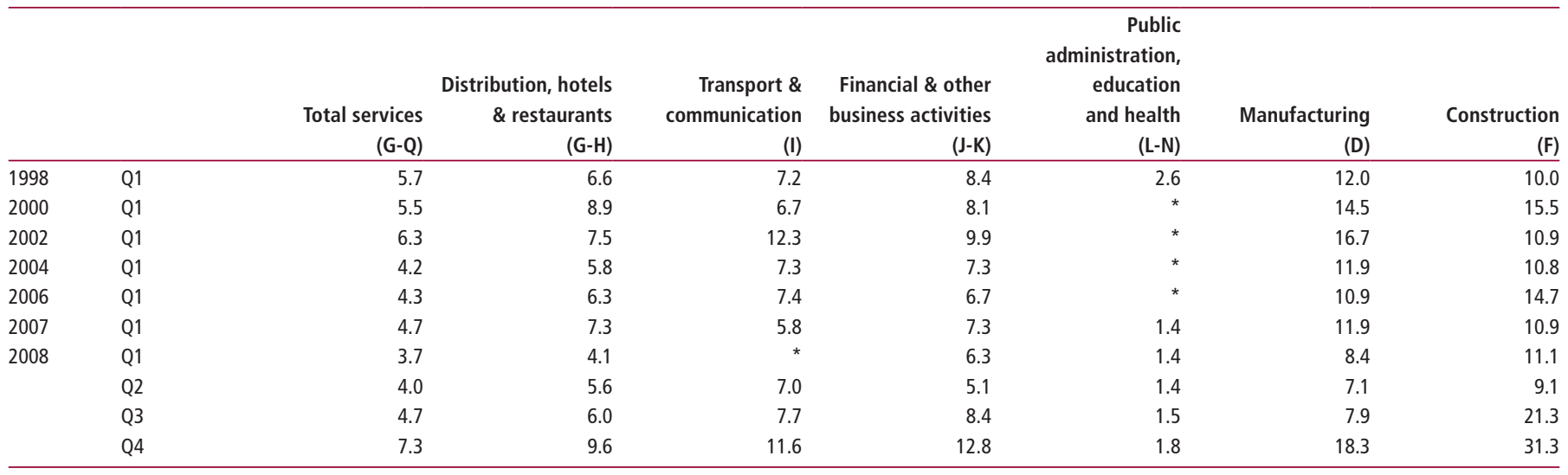

\section{Note:}

1. The redundancy rate is based on the ratio of the redundancy level for the given quarter to the

number of employees in the previous quarter multiplied by 1000 .

* indicates that sample sizes are too small to provide estimates.

\section{Table 8}

\section{Vacancy rates in the services sector}

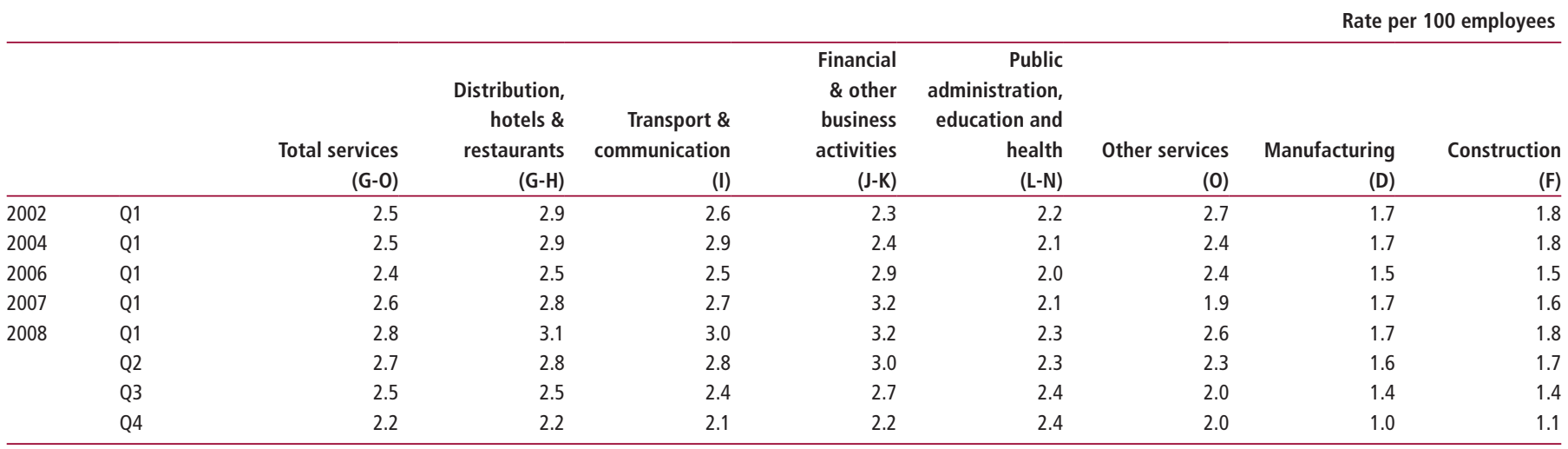

followed by Transport and communication with 11.6

A new vacancy survey was introduced by ONS in 2001 to replace estimates derived from Jobcentre vacancies, which were not fully representative. The monthly Vacancy survey of businesses is sampled from the IDBR and stratified by both industry and employment size. From a sample of 6,000 about 25 per cent are large businesses which are included as a panel, and the remaining sample is retained in the survey for either 5 or 8 months depending on the employment size. Vacancy rates are seasonally adjusted and published monthly in terms of three month averages and include a breakdown by industry. The vacancy rates are seasonally adjusted but not for redundancy rates. For comparability reasons, it is desirable that redundancy rates are also seasonally adjusted.

Table 8 shows the vacancy rate for selected years since 2002 and for each quarter in 2008. In 2008 quarter one, the rate per 100 employees for total services was 2.8 , higher than for the manufacturing (1.7) or construction industries (1.8). This pattern has been consistent for each year from 2002. Vacancy rates have dropped throughout 2008 and in 2008 quarter four were 2.2 in total services, 1.0 in manufacturing and 1.1 in construction. Within the service industries finance and other business services have recorded the highest rate in recent years, but this has now changed with public administration, education and health recording the highest rate at 2.4 in 2008 quarter four.

\section{Conclusions}

ONS has a rich set of data covering service sector performance and labour market characteristics, with consistent time-series being available for most outputs. These complement the employment, output and trade data discussed in an earlier ELMR paper (see Brook 2008). Most of the outputs discussed in this paper include publication of high level dis-aggregates for the service industries.

A notable exception is the quarterly productivity release where currently the only dis-aggregation is for distribution, hotels and restaurants (G-H). ONS are currently investigating the feasibility of including productivity estimates for more service detail, particularly for the market sectors.

Apart from labour market data, most disaggregations are at a high level with sample size limitations in the relevant surveys being the main reason why more sector breakdowns are not available. In some cases it is desirable that the level of detail is improved to allow outside users and government departments to meet policy needs.

Although detailed industry disaggregations can be derived for many labour market characteristics, there can be uncertainty about the quality of the industry classification in the LFS, since 
respondents can miss-report their industry classification. The ONS has investigated the feasibility of improving the LFS industry classification by accessing details from the IDBR to assist respondents in identifying their employer. This had limited success due to identification difficulties, limited resources and confidentiality requirements. Measures to improve LFS industry classification are still needed and should be considered further by the ONS.

ONS is currently developing FATS data in accordance with a new EU regulation. Completion of this work will be of major benefit to assist in investigating issues such as globalisation and outsourcing. Other developments to identify and measure intangible investments are also ongoing and may lead to improvements in the measurement of service sector characteristics.

The ASHE publication includes comprehensive quality measures for each output in terms of the coefficient of variation, the ratio of the standard deviation to the estimate. These are presented in a transparent way with outputs colour coded in tables and banded according to the level of quality (see Tables 5 and 6). Except for ASHE, guidance on quality is limited for the performance measures considered in this paper. The ASHE information is a good standard that other ONS outputs should aim to adopt. Some outputs are derived from a number of sources and in such cases deriving an explicit standard error may be difficult, although using approximate variances based on a simplified sample design may be possible. Other alternatives include the use of sample sizes as a proxy for standard errors, for example for the LFS.

The performance and labour market characteristics discussed in this paper provide a much-needed source of data to allow policy and planning to be undertaken for the service sector and other industries. This is becoming increasingly important with the downturn in the UK and world economy

\section{CONTACT}

(凶)elmr@ons.gsi.gov.uk

\section{REFERENCES}

BERR (2008a) 'BERR's role in raising productivity: new evidence', BERR Economics paper No. 1, February 2008, and at www.berr.gov.uk/files/file44504.pdf

BERR (2008b) 'Supporting Innovation in Services', joint BERR and DIUS report, August 2008, and at www.berr.gov.uk/files/file47440.pdf
Brook A K (2008) 'Developments in measuring the UK service industries, 1990 to 2006', Economic \& Labour Market Review 2(1), pp 18-29, and at www.statistics.gov.uk/elmr/01_08/ downloads/ELMR_Jan08_Brook.pdf

DTI (2006) 'UK Productivity and Competitiveness Indicators 2006', DTI Economics Paper No. 17, March 2006, and at www.dti.gov.uk/files/file28173.pdf

DTI (2007) 'Innovation in services,' DTI Occasional paper No 9, June 2007, and at www.dti.gov.uk/files/file39965.pdf

Eurostat (2007) 'Recommendations Manual on the production of Foreign Affiliates Statistics (FATS)', Eurostat methodologies and working papers, published 2007 and at epp.eurostat.ec.europa.eu/cache/ITY_ OFFPUB/KS-RA-07-002/EN/KS-RA-07-002EN.PDF

HMT (2007) 'Intangible investment and Britain's productivity', Treasury Economic working paper No. 1, October 2007 and at www.hm-treasury.gov.uk/d/pbr_csr07_ macroeconomic333.pdf

ONS (2007) 'The ONS Productivity Handbook', published July 2007 and at www.statistics.gov.uk/about/data/guides/ productivity/default.asp 